\title{
RPLP0 wt Allele
}

National Cancer Institute

\section{Source}

National Cancer Institute. RPLPO wt Allele. NCI Thesaurus. Code C148008.

Human RPLPO wild-type allele is located in the vicinity of 12 q24.23 and is approximately 5 $\mathrm{kb}$ in length. This allele, which encodes $60 \mathrm{~S}$ acidic ribosomal protein $\mathrm{PO}$, is involved in the structure of the ribosome. 